\title{
What Should We Learn about Dewey in China?: An Unfinished Task
}

\author{
Jessica Ching-Sze Wang \\ Professor, National Chiayi University, Taiwan, Department of Education, \\ Chiayi University, Taiwan, China \\ chingsze@mail.ncyu.edu.tw
}

\begin{abstract}
As a response to Michael Peters' essay, "10o years of Dewey in China," the article takes up Peter's question about Dewey's lack of responses to "Chinese problems." It asks a new question about what can be done differently-particularly in important intercultural exchanges, such as that between Dewey and his Chinese disciples. It points to the importance of seeing both self and other as intellectual equals in order to make the exchange experience most educationally worthwhile for both parties.
\end{abstract}

\section{Keywords}

Dewey - China - May $4^{\text {th }}$ Movement - democracy $-\mathrm{Hu}$ Shih - intercultural exchange

Michael Peters' article, "100 years of Dewey in China, 1919-1921-A Reassessment," is divided in two major parts. In the first part, Peters recounts the story of Dewey's 2-year encounter with May 4th China, referring to various dimensions and issues surrounding the visit, including Dewey's own impressions, the reception and appropriation of his ideas, the relationship between Dewey's philosophy with Confucianism and Chinese Marxism. In his review of literature, Peters notes that many studies address similarities, such as that between Dewey and Confucius, but downplay conflicts, such that between Dewey's form of liberal democracy and Chinese Marxism. For Peters, the connection between Dewey and Marx, in terms of their respective roles in the development of modern China and the connection of their philosophies to each other, is intriguing and worth exploring. Today, the question of how one should 
re-connect Dewey to China is an important topic on its own. Peters' paper, I believe, may help to open up new pages with new questions.

In the second part of the paper, Peters sets out to review the rediscovered lectures of Dewey's social and political philosophy delivered in China but appeared for the first time in 2015. In these lectures, Dewey was concerned with the nature of social reform; he proposed the pragmatic method of social inquiry in keeping with his moral and educational vision about democracy and education, which emphasizes free speech, communication and inquiry. Peters assesses these lectures based on Dewey's responses, or lack of responses, to "Chinese problems" and "Chinese differences."

Peters claims that "accounting for the Chinese difference is a problem for Dewey because he does not have enough acquaintance with Chinese history and culture to understand its internal development." Peters stresses this point once again when he states that "Dewey detects the Chinese difference but did not have enough detailed understanding of Chinese history and philosophy to give it a definite form." Although I take Peters' statements to be general comments, rather than criticisms, I could not help but wonder whether more could be done, and done differently.

In my book, John Dewey in China: To Teach and To Learn (2007), I show that Dewey tried, to the best of his ability, to play his role as a teacher and a learner. However, I did not ask the question of whether his teaching and learning could be better assisted to bring about more meaningful results, both for himself and the Chinese. Now I take this opportunity here to probe this question, if not answer it. My purpose is to use the past to illuminate the present or enlighten the future.

I would like to start by acknowledging my own puzzlement: during his stay, how often did Dewey have a chance to fully engage himself in dialogue and inquiry with his disciples regarding matters of importance in China? As a foreign visitor, Dewey could not have conducted this "social inquiry" alone. He needed "critical friends" to exchange different views and challenge hidden assumptions.

In his letters and articles about China, Dewey did not mention much about his dialogues with his disciples (granted that they spent a lot of time traveling together). Perhaps they did talk and learned from each other, and Dewey did not care to mention them. Or perhaps they did not have many chances to really engage in dialogue and inquiry with each other, and I wonder why. I wonder whether Dewey's disciples were too busy introducing and appropriating his ideas, rather than engaging themselves intellectually with Dewey as equals and as critical friends. 
If Dewey's Chinese hosts were more ready to play their roles as intellectual equals in social inquiry and in philosophical dialogues, Dewey could have been more informed and better educated. Dewey would have learned as much from Hu Shih and many others, as he had learned from his American friends, such as Jane Addams and George Mead.

In my view, in any cross-cultural exchanges and dialogues, such as those between Dewey and his Chinese disciples, it is very important for both parties to play their roles in order for the intellectual exchange to be educationally worthwhile for both. In unequal and ideological power relations, one cannot learn and grow as much. If time is not allowed, and space is never given, the process of inquiry will also be arrested. In that case, Dewey's pragmatic method of inquiry will only remain a high-sounding ideal.

So far I have asked the question of whether Dewey's encounter with May Forth intellectuals could have been different. I found this question intriguing, and yet very difficult to answer. I do not claim to have an objective view. Nevertheless, I find the question particularly important today because more intellectual exchanges are taking place in the world across regional and cultural borders, and we need to reflect upon the qualities of those experiences. Dewey reminds us that the key to democracy lies in local neighborly communities, in face to face relationships, and the question is: we are ready to engage in democratic dialogues with one another about matters of importance? And this takes two parties as equals, not just one. Although a hundred years have passed, the world still has more to learn about Dewey, about China, and about Dewey in China—and the task is not yet finished. 